\title{
Employee Turnover in Deccan Industries, Coimbatore
}

\author{
CS Gowtham Chakravarthi, Gowtham Ashirvad Kumar, Pallavi Kumari
}

\begin{abstract}
Exact investigations of open representative turnover, especially utilizing turnover as a free factor, are uncommon; and the vast majority of the writing expect turnover to negatively affect associations. This investigation looks at a provocative however minimal bolstered speculation that has as of late risen in the private segment writing - that turnover may give positive advantages to the association, at any rate to a limited extent. Utilizing information from a few hundred open associations over a nine-year time span, we test the suggestion that moderate degrees of turnover may decidedly influence hierarchical execution. We find that while turnover is surely contrarily identified with execution for the association's essential objective, it has the speculated nonlinear relationship for an auxiliary yield that is portrayed by more prominent undertaking trouble.
\end{abstract}

Keywords: Turnover, Organizational Performance

\section{INTRODUCTION}

A representative is any individual who has consented to be utilized, under an agreement of administration, to work for some type of installment. [1],[3],[5]

This incorporates:

- Home laborers

- People who have been extended and have acknowledged an employment opportunity

- Fixed-term workers

- Seasonal workers

- Casual and low maintenance workers

- Employees on trial and times for testing.

An employee is not:

- A independently employed or self employed entity

- A realtor whose understanding says they are a self employed entity
- A volunteer who does not get a reward for working

- In a few cases, an individual who is occupied with film generation

$\left.\left.\begin{array}{l}\text { Human capital } \\ \text { effectiveness } \\ \text { Motivational and incentive system } \\ \text { Company }\end{array}\right\} \begin{array}{l}\text { Human capital assets } \\ \text { Human capital liabilities } \\ \text { Corporate }\end{array}\right\} \begin{array}{r}\text { Management } \\ \text { Social structure } \\ \text { attitude\& }\end{array}$

A portion of these advantages incorporate the paid get-away between Diwali, Christmas and New Year's, restricted strategic scheduling accessibility, and health openings. One of the most as often as possible rehashed concerns communicated by representatives with respect to advantages was the significance of guaranteeing that all workers were managed equivalent access to every single accessible advantage and that entrance not be constrained by a boss' restricted translations of an advantage's accessibility or by the idea of one's work. [2],[4],[6]

Interviewees additionally recognized that one's close to home conditions frequently managed how supportive advantages were in diminishing the difficulties innate in adjusting work and family desires. Along these lines, while moderate youngster care may be especially significant for representatives with small kids, this advantage does little to help the worker who is thinking about an old parent. At the end of the day, representatives would be given a rundown of advantage alternatives and financial rules for all out advantages. They would then be permitted to pick the bundle of advantage alternatives most important for their conditions. [7], [9] ,[11]

The kinds of advantages talked about and the way where these advantages would be useful were generally reliable crosswise over center gatherings. The following is a rundown of the most ordinarily refered to benefits, arranged by significance, that representatives distinguished as ones that would be most useful to them in overseeing work and family commitments viably. [8], [10],[12]

\section{RESEARCH INSTRUMENT}

Mr. CS Gowtham Chakravarthi, Department of MBA, Bharath Institute of Higher Education and Research, Chennai, India. Email: chakravins@gmail.com

Gowtham ashirvad kumar, Department of MBA, Bharath Institute of

Higher Education and Research, Chennai, India.

Email: kgowthamaashirwad123@gmail.com

Pallavi Kumari, Department of MBA, Bharath Institute of Higher Education and Research, Chennai, India.

Email: palalvikumari@gmail.com 


\section{Employee Turnover in Deccan Industries, Coimbatore}

the poll. The survey comprises of various inquiries imprinted in a distinct request on a structure or set of structures. The poll is mail to respondents who are required to peruse and comprehend the inquiries and record the answer in the space loaned for the reason in the survey itself. The respondents need to address the inquiries all alone [13], [15],[17]

In this investigation, a survey was utilized to gather information from the example.

\section{B. Sample Design}

Test configuration alludes to the system or the method the examination would embrace in choosing the thing for the example. Basic arbitrary example is a subset of person's choses from a bigger set. Every individual is picked arbitrarily and totally by some coincidence, with the end goal that every individual has a similar likelihood of being picked at any phase during inspecting process.

\section{Population of the Study}

An exploration populace is commonly an enormous gathering of people or article that will be that fundamental focal point of a logical inquiry. It is to help the populace that looks into are finished [14], [16],[18]

An exploration populace is additionally knows as a well-characterized accumulation of people item to knows as comparable article.

Deccan Industries incorporates 174 workers.

\section{Sample Size} Industries

Data is collected from 121employees of Deccan

\section{E. Statistical Tools For Data Analysis}

This research has used the following statistical tools

- Percentage Analysis

- Frequency Analysis

- Chi-Square Test

\section{DATA COLLECTION}

Table -1 Working condition for this classification
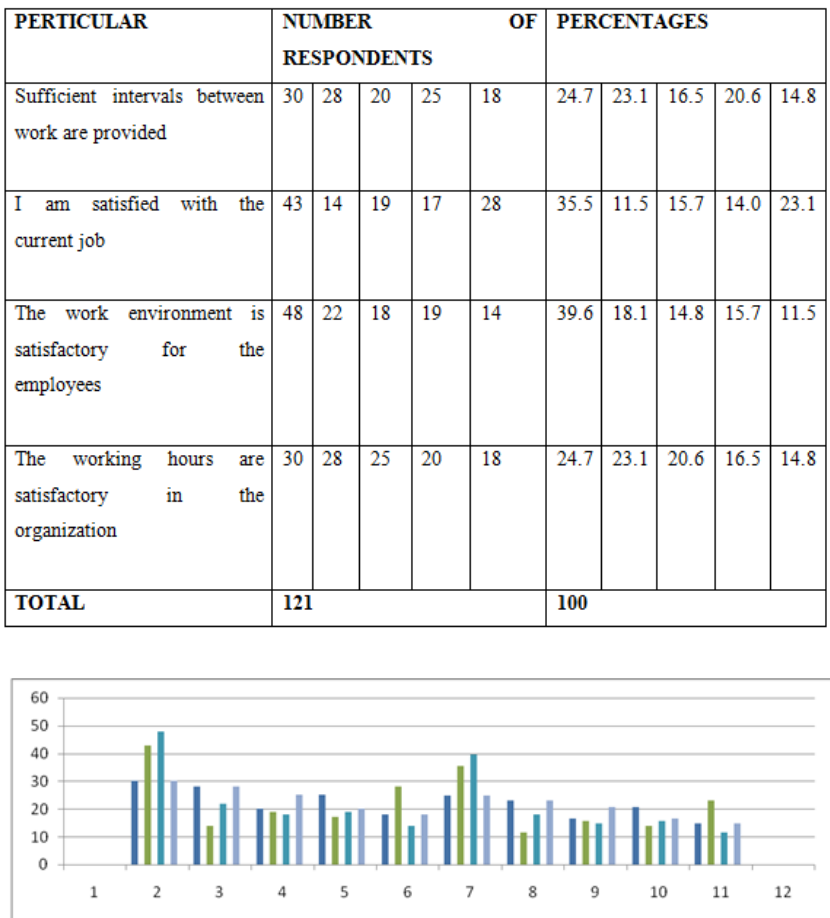

Figure - 1Working condition for this classification

\section{Inference}

From the table 4.11 (4) it is inferred that the sufficient intervals between $24.7 \%$ of the high volume of this category and below $14.8 \%$ of the category. The job satisfaction of this company is $35.5 \%$ of the category and below $11.5 \%$ of the unsatisfied of this company. The work environment satisfactory was $39.6 \%$ of this category. The less than $11.5 \%$ of the lowest range in the category. The working hours of the $24.7 \%$ people are satisfied to the job .but $14.8 \%$ people unsatisfied to these working hours.

Table -2 Welfare/ safety measures for this classification

\begin{tabular}{|l|l|l|l|l|l|l|l|l|l|l|l|}
\hline PERTICULAR & \multicolumn{1}{|l|}{$\begin{array}{l}\text { NUMBER } \\
\text { RESPONDENTS }\end{array}$} \\
\hline $\begin{array}{l}\text { Adequate first-aid facilities } \\
\text { are provided }\end{array}$ & 22 & 48 & 19 & 18 & 14 & 19.1 & 39.6 & 15.7 & 14.8 & 11.5 \\
\hline $\begin{array}{l}\text { The factory premises are } \\
\text { clean \& health }\end{array}$ & 22 & 48 & 24 & 17 & 16 & 18.1 & 39.6 & 19.8 & 14.0 & 13.2 \\
\hline $\begin{array}{l}\text { Canteen facilities are } \\
\text { hygienic and satisfactory }\end{array}$ & 22 & 48 & 14 & 20 & 17 & 18.1 & 39.6 & 11.5 & 16.5 & 14.0 \\
\hline TOTAL & $\mathbf{1 2 1}$ & & & & & & & & & & \\
\hline
\end{tabular}

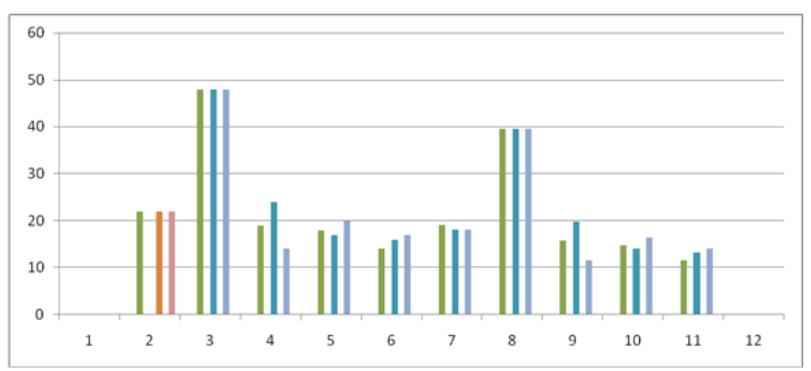

Figure - 2 Welfare/ safety measures for this classification 


\section{Inference}

From the above table 4.11(5)it is inferred that the high level of the first aid facilities are provided $39.6 \%$ people are support this company and $11.5 \%$ people are unsatisfied to the first aid facilities. The company clean and health was $39.6 \%$ of the high level of satisfied and $13.2 \%$ of the unsatisfied for the people chooses. The hygienic food will provided to the company canteen are $39.6 \%$ of the people will satisfied $11.5 \%$ of the people are un satisfied to the providing hygienic food facilities of this company category.

Table -3 Motivation for this classification
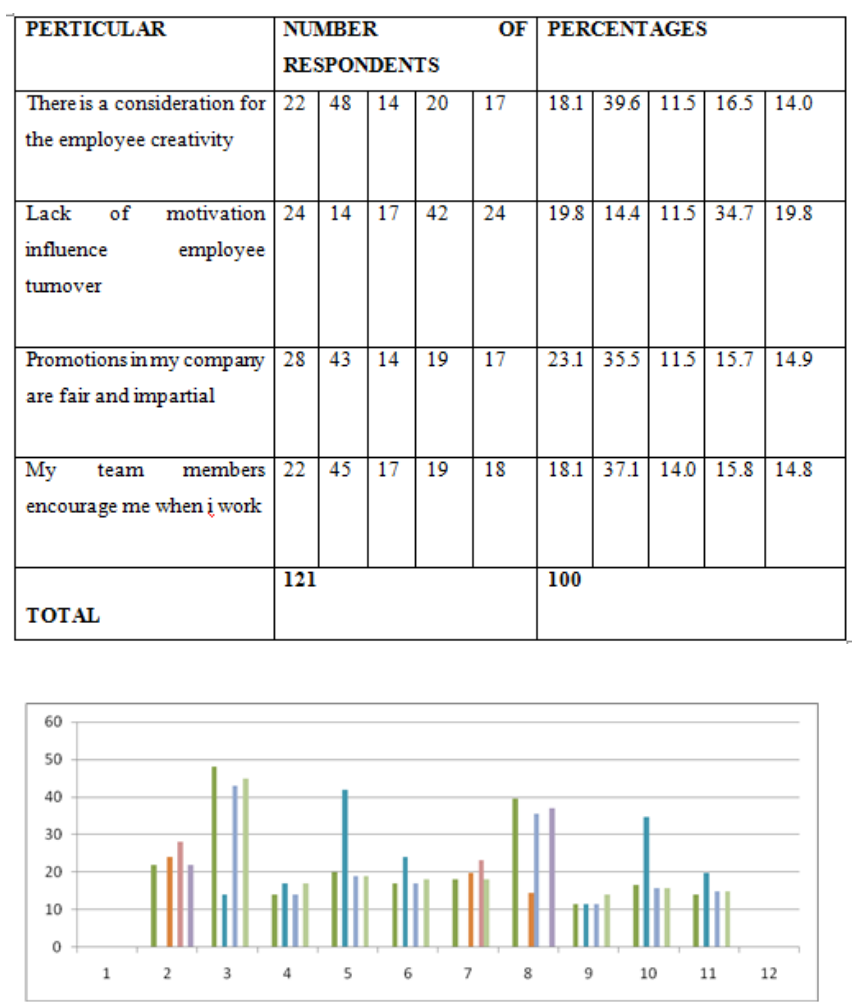

Figure - 3 Motivation for this classification

\section{Inference}

From the table 4.11(5) it is inferred that the consideration of the employee creativity is $39.6 \%$ of the high level of this satisfaction, and $11.5 \%$ of low level of this level. Most important factor of motivation influence employee turnover was $34.7 \%$ level and $11.5 \%$ of the below level of the employee turnover. The other factor of promotion of the company fair wills high volume of $35.5 \%$ of this category, and $11.5 \%$ of the lowest category. Team member encourage was provided to $37.1 \%$ and below $14.0 \%$ level of this satisfactory in this company.

\section{INFERNTIAL ANALYSIS}

1) Test: Test whether level of employee turnover of employee at moderate level

Tools used: CHI-SQUARE

\section{Variable: nominal}

\section{Hypothesis}

Ho: Level of employee turnover of employees is equal to moderate level.
H1: Alternative hypothecs.

\section{Output}

\begin{tabular}{|l|l|l|l|l|}
\hline Level of LET & Observed Mean & Expected Mean & Z-Value & P-Value \\
\hline Low & 35 & 40.3 & & \\
\hline Moderate & 54 & 40.3 & 7.058 & 0.029 \\
\hline High & 32 & 40.3 & & \\
& & & & \\
\hline
\end{tabular}

\section{INFERENCE:}

Since $\mathrm{P}-$ Value is less than $0.05 \mathrm{Ho}$ is rejected at $1 \%$ level of significance. Hence conclude that there is difference in opinion regarding Level of employee turnover of employees are not equal to moderate level.

\section{RESULTS}

Through this overview it is discovered that $(70.2 \%)$ of the respondents are male so the Employee turnover completely reliant on Male representatives.

- From the investigation demonstrates that (38.0\%) is a most no respondent are period of over 41 years

- Most of the businesses are given over 15000 compensations by the organization.

- The study is presumed that $(46.3 \%)$ of representatives have understanding over 15 years.

- From the examination the purpose for that to leave the past activity for the most part relies upon the awkward working condition and welfare and security measure.

- The review infers that $(38.8 \%)$ of the respondents have beneath 1 years of involvement in the association.

- More no of (27.3\%) respondent's supposition about purposes behind leaving present place of employment due to awkward working condition. [19], [21],[23]

- The review infers that the dominant part (31.82\%) of respondents are happy with the compensation paid is equivalent to work done.

- Majority of the $(28.1 \%)$ respondents are concur with the compensation paid is proportional to comparative organization.

- Through this review it is the lion's share (38.8\%) of respondents concur with the work gave between adequate interim. [20], [22], [24]

- The examination demonstrates most no of (24.00\%) respondents concurred that they have great association with their bosses.

- From the investigation most extreme number of $(34.7 \%)$ respondents are concur with the activity fulfillment.

- It is discovered that larger part of (22.3\%) respondents concurred that their give directing to their activity. 


\section{Employee Turnover in Deccan Industries, Coimbatore}

- The overview presume that $(27.3 \%)$ of the respondents concurred that their desires met after joined the association.

- The most extreme number of (27.3\%) respondents concurred that they outside weight at work and furthermore $(23.1 \%)$ of the respondents unequivocally differ that they outer weight at work.

- There are progressively number of (28.1\%) respondents concurred that they are happy with working hours.

The overview presumes that most of $(35.5 \%)$ respondents are concurred with the preparation software engineers.

- Among the general respondents of (33.9\%) the respondents concurred that the association has given sufficient medical aid office.

- The investigation demonstrates that the more respondents $(21.5 \%)$ are firmly concurred that the association premises have perfect and sound.

- The studies reason that the most respondents $(21.3 \%)$ are concurred that the association had supported your work.

- The study reasons that most of (21.5\%) the respondents concurred that the organization has flask offices are clean and palatable.

- Majority of the $(42.73 \%)$ respondents differ that the activity is disappointed.

- It is discovered that the greatest number of (27.3\%) respondents have purpose behind leaving association better awkward working condition [25], [27], [29]

- Majority of the $(28.18 \%)$ of the respondents remain back in this association for higher pay/compensation.

\section{V.DISCUSSIONS}

Recruit the male and female representative are similarly.

- To revive worker mind, for change and to decrease their outstanding task at hand organization must mastermind visit, get-together, picnics software engineers.

- To rouse the representative they should gave remuneration, rewards motivating forces to the worker.

- Try to diminish the hole between top administration and representative.

- Try to keep up relational connection between top administration and worker.

- Try to discover the explanation for their low execution and keep up the great association with representative.

- There are increasingly number of respondents concurred that they are happy with working hours, they have kept up consistently.

- Company ought to orchestrate workshop and different developers, for example, delicate ability stress the board software engineers for the representatives.

- Respect in the work spot was uncovered to be a key factor in deliberate turnover and discovers approach to develop and nature regard in your work environment. [26], [28], [30]

- Proper advancement must be given to all of the workers.

\section{CONCLUSION}

The discoveries of the examination would empower the organization to improve its exhibition to a more noteworthy degree. Teaching esteems like trust and responsibility among the representatives is the most ideal approach to keep down abilities in an association Employees leave the association for more significant compensations as well as for awkward working condition. Truth be told, there is a point of confinement to the compensations a business can stand to pay occasions best performing workers.[31], [33]

Or maybe, the serious issues lie with the unstated needs of the representatives. They anticipate that the administration should get an up front investment from them on basic choices that influence the association. The human asset office has a basic task to carry out in this association singular competency arrangement. The duty of foreseeing procedure and individual execution levels dependent on industry patterns is altogether on the HR group. They have to chip away at the current information on exhibitions and create activities plans for individual level execution the executives.

At long last, bosses need to deal with every one of the variables that influence a representative, while defining successful worker maintenance modified. The components can be epitomized as Confidence and Trust, and Listening.

\section{REFERENCES}

1) BharthVajan R., Ramachandran S.,Psychographic dimensions of training,2016,International Journal of Pharmacy and Technology,V-8,I-4,P-23727-23729

2) Balakrishnan P., Bharthvajan R.,A study on human resource planning in hospitals in Chennai City,2014,International Journal of Applied Engineering Research,V-9,I-22,P-7503-7507

3) Priyadarsini P., Bharthvajan R.,Role of emotional intelligence training programme in reducing the stress of the nurses,2014,International Journal of Applied Engineering Research,V-9,I-22,P-7411-7421

4) Kerinab Beenu G., Bharthvajan R.,Empirical analysis on the cosmetic buying behavior of young women in South India,2014,International Journal of Applied Engineering Research,V-9,I-22,P-7361-7366

5) Balakrishnan P., Bharthvajan R.,Whistling in the wind,2014,International Journal of Applied Engineering Research,V-9,I-22,P-7586-7593

6) Krishnan B., Peter M.,Health hazards of Indian Bpo employee-an alarming issue,2014,International Journal of Applied Engineering Research,V-9,I-22,P-7336-7341

7) Kerinab Beenu G.H., Peter M.,Role of insurance in economic development,2014,International Journal of Applied Engineering Research,V-9,I-22,P-7532-7539 
8) Balakrishnan P., Peter M., Priyadarsini P.,Efficiency of safety measures for wellbeing of employees in manufacturing industry,2014,International Journal of Applied Engineering Research,V-9,I-22,P-7376-7382

9) Anbarasi M., Praveen Kumar S.,Online sales promotions of herbal products and its effectiveness towards tanisha.com,2019,Indian Journal of Public Health Research and Development,V-10,I-1,P-195-200

10) Anbarasi M., Praveen Kumar S.,Various online marketing and promotions strategies to improve the validation towards the organic products in the pharmaceutical sectors,2019,Indian Journal of Public Health Research and Development,V-10,I-1,P-263-269

11) Loganathan R., Praveen Kumar S.,Grievance handling a key factor for solving issues of employees in an organization,2014,International Journal of Applied Engineering Research,V-9,I-22,P-7483-7491

12) Loganathan R., Praveen Kumar S.,Study on preference of private label brands in super and Hypermarkets,2014,International Journal of Applied Engineering Research,V-9,I-22,P-7327-7335

13) Smitha M., Praveen Kumar S.,Understanding stress and its managementamong the nurses in Chennai city,2014,International Journa of Applied Engineering Research,V-9,I-22,P-7560-7565

14) Kerinab Beenu G.H., Praveen Kumar S.,A study on the investment behavior of Chennai investors in mutual fund schemes,2014,International Journal of Applied Engineering Research,V-9,I-22,P-7520-7525

15) Loganathan R., Praveen Kumar S.,Retention strategies key for organizational productivity,2014,International Journal of Applied Engineering Research,V-9,I-22,P-7443-7447

16) Pavithra J., Ganesan M., Brindha G.,State wise analysis of microfinance sector in India,2016,International Journal of Pharmacy and Technology,V-8,I-4,P-23417-23432

17) Pavithra J., Ganesan M.,A comparative study on microfinance in India and abroad,2016,International Journal of Applied Business and Economic Research,V-14,I-8,P-5471-5476

18) Pavithra J., Ganesan M.,A study on awareness and impact of micro-financial schemes,2016,International Journal of Applied Business and Economic Research,V-14,I-8,P-5449-5460

19) Senthilmurugan P., Pavithra J.,Consumer preference towards organised retailing with reference to Big Bazaar,2014,International Journal of Applied Engineering Research,V-9,I-22,P-7469-7475

20) Senthilmurugan P., Pavithra J.,Implication of social media marketing in growing healthcare industry,2014,International Journal of Applied Engineering Research,V-9,I-22,P-7448-7456

21) Loganathan R., Pavithra J.,Consumer perception towards private label brand over other brands in super markets and hypermarkets,2014,International Journal of Applied Engineering Research,V-9,I-22,P-7355-7360

22) Kerinab Beenu G., Pavithra J.,Tradeâ€"off between liquidity and profitability in logistics industry,2014,International Journal of Applied Engineering Research,V-9,I-22,P-7398-7401

23) Kerinab Beenu G., Pavithra J.,A study on the prospective consumerâ€ TM $_{\mathrm{S}}$ perception towards utility cars in Chennai city,2014,International Journal of Applied Engineering Research,V-9,I-22,P-7526-7531

24) Pavithra J., Dilli Babu P., Ambuli T.V.,A study on budgetary control at Maruti Service Masters, Chennai,2014,International Journal of Applied Business and Economic Research,V-12,I-2,P-151-161

25) Pavithra J., Dilli Babu P., Ambuli T.V.,A study on customer satisfaction of retro Garments Pvt Ltd, Chennai,2014,International Journal of Applied Business and Economic Research,V-12,I-2,P-381-391

26) Kerinab Beenu G.H., Pavithra J., Senthilmurugan P.,A study on the influence of promotional activities for TATA ARIA among consumers in Chennai,2014,International Journal of Applied Engineering Research,V-9,I-22,P-7572-7578

27) Vijayaragavan S.P.,An investigative expert that's general FBG sensors, International Journal of Mechanical Engineering and Technology,V-8,I-8,PP-1500-1505,Y-2017

28) Vijayaragavan S.P.,Equalization routing protocol for Wi-Fi sensor strategy,International Journal of Mechanical Engineering and Technology,V-8,I-8,PP-1662-1666,Y-2017

29) Karthik B., Kiran Kumar T.V.U., Vijayaragavan P., Bharath Kumaran E.,Design of a digital PLL using 0.35 $\hat{\mathrm{I}}^{1 / 4 \mathrm{~m}}$ CMOS technology,Middle East Journal of Scientific Research,V-18,I-12,PP-1803-1806,Y-2013

30) Kanniga E., Selvaramarathnam K., Sundararajan M.,Kandigital bike operating system,Middle - East Journal of Scientific Research,V

31) Jasmin M., Vigneshwaran T., Beulah Hemalatha S.,Design of power aware on chip embedded memory based FSM encoding in FPGA,International Journal of Applied Engineering Research,V-10,I-2,PP-4487-4496,Y-2015

32) Jasmin M.,Optimization techniques for low power VLSI circuits,Middle East Journal of Scientific Research,V-20,I-9,PP-1082-1087,Y-2014

33) Jasmin M., Vigneswaran T.,Fuzzy controller for error control of on - Chip communication,2017 International Conference on Algorithms, Methodology, Models and Applications in Emerging Technologies, ICAMMAET 2017,V-2017-January,I-,PP-1-5,Y-2017

\section{AUTHORS PROFILE}

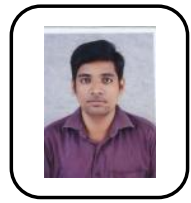

Mr. CS Gowtham Chakravarthi Assistant Professor, Department of MBA, Bharath Institute of Higher Education and Research, Chennai, India.

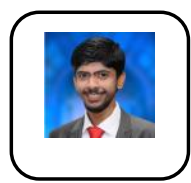

Gowtham ashirvad kumar Assistant Professor, Department of MBA, Bharath Institute of Higher Education and Research, Chennai, India.

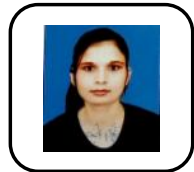

Pallavi Kumari Student, Department of MBA, Bharath Institute of Higher Education and Research, Chennai, India. 